\title{
Nutrient and Anti-nutrient Composition and the Influence of Dietary Incorporation of Time- course Fermented African Locust Bean Seeds on Growth Performance of Wistar Rats
}

Godwin Ekpo Okon

Department of Biochemistry, Faculty of Basic Medical Sciences, University of Calabar, Calabar, Nigeria.

Email: godwinokon27@gmail.com

Copyright: @2021 Godwin Ekpo Okon. This is an open access article distributed under the terms of the Creative Commons Attribution License, which permits unrestricted use, distribution, and reproduction in any medium, provided the original author and source are credited.

\section{ABSTRACT}

The nutrient and anti-nutrient composition of African locust bean (Parkia biglobosa) seeds and the effects of dietary incorporation of its time-course fermentation products on growth performance of Wistar rats was assessed in this study. Nutrient and anti-nutrient composition of unfermented and fermented products were analyzed using recommended methods. Fifty-four (54) male Wistar rats weighing between $120 \mathrm{~g}$ to $150 \mathrm{~g}$ (about 6 weeks old) were randomly divided into nine groups of six rats each. The unfermented and fermented seeds were incorporated into the diets of Wistar rats at $20 \%$ and 50\% inclusion levels and served as treatments. Group 1 served as normal control and was fed with 100\% growers mash while groups 2 to 9 served as experimental and was fed with unfermented and fermented products (day 1,2 and 3) at different inclusion levels (20\% and 50\%). Treatment lasted for a period of 21 days and the indicators of growth performance were calculated within the entire duration of treatment. The result for proximate composition revealed that fermentation caused changes in the nutrient parameters of the seeds. Moisture, protein and fat content were increased by fermentation whereas fibre and carbohydrate content were decreased by fermentation. It was also observed that fermentation reduced $(p<0.05)$ all levels of anti-nutrients present in the unfermented seeds. The groups fed with fermented seeds had significantly $(P<0.05)$ elevated weight gain when compared against the groups fed with the unfermented (UF) products. Feed intake scores of groups fed with UF products was significantly $(P<0.05)$ higher than the scores of the groups fed with fermented products. However, a decreased $(P<0.05)$ feed conversation ratios was observed in the groups fed with fermented products when compared to the groups fed with UF products. Thus, the fermented seeds (notably the D3F product) improved the growth performance of the rats.

Keywords: Parkia biglobosa, Fermentation products, Dietary incorporation, Growth performance.

\section{Introduction}

The African locust bean tree (Parkia biglobosa) is a very significant, multipurpose tree. The tree is often planted in and around villages for its many uses, whilst it has also become widely planted in agroforestry systems throughout the tropics, where it provides shade and shelter for the other crops ${ }^{[1]}$. P. biglobosa occurs mainly in communities where bush fallow system predominates and cultivation is semi-permanent.

The tree is a fire-resistant heliophyte with capacity to survive drought conditions. The characteristic bright capitulum of $P$. biglobosa which measures about $45-70 \mathrm{~mm}$ long and about $35-60 \mathrm{~mm}$ in diameter holds up to 2500 flowers that are arranged along a sphere-shaped shoot. Mature flowers are about $15 \mathrm{~mm}$ long having anthers of about $1.5 \mathrm{~mm}$ in length ${ }^{[2]}$. The fruit is utilized in different ways.

They are thought have more economic relevance than other products excluding the seeds. P. biglobosa begins to fruit around 8 years. The seed pods are first green and fleshy when young and as they mature, they darken to brown and become very woody. The pod has a sub-cylindrical shape and each contains approximately 5-20 seeds implanted in rough yellow endocarp (which is called dozim in Nigeria ${ }^{[3]}$. The oval seeds of about $1.5 \mathrm{~cm}$ long and about $1.0 \mathrm{~cm}$ wide are made up of $30 \%$ integument and $70 \%$ seed leaf ${ }^{[4]}$.

The seed is protected from the natural harsh conditions of the savanna by the thick seed coat. ${ }^{[5]}$. The tree is distributed across zones where rainfall averages $800 \mathrm{~mm}$ to $1500 \mathrm{~mm}$. P. biglobosa is reported to be identified in about 19 countries in ${ }^{[3]}$. The seeds of $P$. biglobosa are usually fermented and utilized traditionally as a spice ${ }^{[6]}$. In 
the savanna regions of sub-saharan Africa, seeds of P. biglobosa are fermented and formulated into a spice used to season stews and soups ${ }^{[4]}$. The fermentation of P. biglobosa seeds for commercial purposes is an important economic activity for women in West Africa. Scientific studies have revealed that the seeds of P. biglobosa are excellent source of protein including essential amino acids ${ }^{[7]}$.

Because of its high protein content, these fermented seeds are widely consumed in rural settings because the availability of animal protein is limited by factors relating to economy and culture ${ }^{[8]}$. The nutritional benefit of a food or food product is as a result of its biochemical composition. P. biglobosa seeds are primarily composed of almost $40 \%$ proteins, $35 \%$ fats and about $12 \%$ carbohydrates ${ }^{[4]}$. Available literatures on the microbial aspect of $P$. biglobosa seeds fermentation identify the Bacillus spp. as primary fermenting organisms with Bacillus subtilis being the most predominant species ${ }^{[9]}$. Some workers have shown that Leuconostoc mesenteroides and Staphylococcus spp. are also involved in the fermentation of P. biglobosa seeds ${ }^{[10]}$.

They proposed that although $B$. subtilis is the dominant fermenting agent after 24 hours, several other microorganisms are associated with the fermentation of $P$. biglobosa seeds. Studies on the anti-nutrient profile of the unfermented seeds of $P$. biglobosa by earlier workers ${ }^{[8]},{ }^{[11]},{ }^{[12]}$ have revealed that the seeds contain anti-nutrients such as trypsin inhibitor, oxalates, saponins, phytates and tannins and that these anti-nutrients are significantly reduced by fermentation. Fermenting the seeds of $P$. biglobos $a$ also releases some bioactive principles specifically flavonoids and some phenoliccs ${ }^{[11]}$. The proximate composition of foods includes moisture, ash, lipid, protein and carbohydrate contents. These food components may be of interest in the food industry for product development, quality control or regulatory purposes ${ }^{[13]}$.

Antinutritional factors are primarily associated with compounds or substances of natural or synthetic origin, which interfere with the absorption of nutrients, and act to reduce nutrient intake, digestion, and utilization and may produce other adverse effects. Antinutrients are frequently related to plant-based, raw or vegan diets and are naturally synthesized in plants ${ }^{[14]}$. Some of the common symptoms exhibited by a large number of antinutrients in the body can be nausea, bloating, headaches, rashes, as well as nutritional deficiencies ${ }^{[15]}$. On the other hand, such chemical compounds can be evidently advantageous to humankind when consumed wisely. In fact, plants, for their own defense, primarily use antinutrients.

Although perceptions to antinutrients widely differ, adequate food processing is initially recommended to reduce antinutritional factors ${ }^{[16]}$. Many traditional preparation methods such as fermentation has been shown to reduce antinutrients, such as phytic acid and increase the nutritional quality of plant foods and are widely used in societies where cereals and legumes are a significant part of the diet ${ }^{[17]}$. Experimentally, growth performance is assessed by feeding a typical food product to an organism and assessing specified growth indices periodically.

\section{Materials and methods}

\subsection{Procurement of materials}

P. biglobosa seeds were procured from Okuku Central Market, Yala Local Government Area of Cross River State. Experimental animals were obtained from the Animal House, University of Calabar, Calabar. 


\subsection{Seed preparation and fermentation}

The seeds were traditionally fermented. They were boiled in water, using a large metallic pot, with wood fire for 8 hours. Water was added at intervals to replace the quantity of water lost through vaporization. After boiling, the seeds were pounded lightly using wooden mortar and pestle to separate the cotyledons from the seed coat. The cotyledons was then boiled for 1 hour with fresh water after which they were poured into a basket made of oil palm fronds and covered with paw-paw leaves to prevent rapid heat loss. The seeds were separated into four fractions. The first fraction was collected prior to incubation. This was the unfermented seeds. The second fraction was incubated for 24 hours to obtain day 1 fermented seeds. The third fraction was incubated for 48 hours to obtain day 2 fermented seeds and the remaining fraction was incubated for 72 hours to obtain day 3 fermented seeds. All seeds were allowed to ferment within ambient temperature. The unfermented and fermented seeds (day 1,2 and 3) were dried under the sun for 72 hours and kept away from dust and insects. The seeds were then pulverised using a manual blender and powdered seeds kept in air-tight plastic containers until required for use.

\subsection{Animal collection, handling and feeding (treatment)}

Fifty-four (54) apparently healthy male Wistar rats of about 6 weeks old with weight range of $120 \mathrm{~g}$ to $150 \mathrm{~g}$ were obtained from the Animal House, University of Calabar, Calabar, and used for the study. The animals were housed in well ventilated cages at standard conditions of temperature $\left(25^{\circ} \mathrm{C}\right)$ and supplied with good drinking water. The experimental rats were separated into nine groups of six (6) per group; eight out of the nine groups were fed with the formulated diets of $P$. biglobosa seeds. The fermented and unfermented products of P. biglobosa seeds were included in the feeds at $20 \%$ and $50 \%$ dietary inclusion levels using the formula:

$[x \times 20 / 80] \mathrm{g}$ of Product $+x \mathrm{~g}$ of pure feed $=20 \%$ dietary inclusion

$[x \mathrm{x}$ 50/50] $\mathrm{g}$ of Product $+x \mathrm{~g}$ of pure feed $=50 \%$ dietary inclusion, where $x$ is the weight of pure feed (growers mash).

The formulated diets were termed "treatments" with the treatment schedule shown in Table 1.

Table 1. Treatment schedule for the experimental rats

\begin{tabular}{ccc}
\hline GROUP & No. of Rats & Treatment \\
\hline 1 & 6 & $20 \% \mathrm{UF}$ \\
2 & 6 & $50 \% \mathrm{UF}$ \\
4 & 6 & $20 \% \mathrm{D} 1 \mathrm{~F}$ \\
5 & 6 & $50 \% \mathrm{D} 1 \mathrm{~F}$ \\
6 & 6 & $20 \% \mathrm{D} 2 \mathrm{~F}$ \\
\hline
\end{tabular}


7

8

9
6

6

6
$20 \% \mathrm{D} 3 \mathrm{~F}$

$50 \% \mathrm{D} 3 \mathrm{~F}$

$100 \%$ Growers mash (NC)

KEY:

$\mathbf{U F}=$ Unfermented products of $P$. biglobos $a$ seeds

D1F $=$ Fermented products of $P$. biglobosa seeds obtained after the first day of fermentation.

D2F $=$ Fermented products of $P$. biglobosa seeds obtained after the second day of fermentation.

D3F $=$ Fermented products of $P$. biglobosa seeds obtained after the third day of fermentation.

$\mathbf{N C}=$ Normal control

Percentages (\%) represent the dietary inclusion levels.

\subsection{Proximate analysis of the unfermented and fermented seeds}

The recommended procedures as outlined by the Association of Official Analytical Chemists ${ }^{[18]}$ were utilized in carrying out the proximate analysis of the fermented and unfermented seeds. Moisture, ash, crude fat, crude fiber, crude protein, total carbohydrates and caloric value were determined. Anti-nutrient analysis was carried out using recommended methods.

\subsubsection{Determination of moisture content}

Two grams of the dried ground samples were weighed into a crucible and placed in an oven at a controlled temperature of $105^{\circ} \mathrm{C}$. The sample was allowed to dry in the oven to a constant weight. The percentage moisture content was then expressed as the percentage of the original weight of the sample. The experiment was carried out in triplicates the percentage moisture was thus calculated: \% moisture $=100 \times[\mathrm{B}-\mathrm{C}] /[\mathrm{B}-\mathrm{A}]$

Where $\mathrm{A}=$ mass of dried crucible

$\mathrm{B}=$ mass of dry crucible + Sample before drying

$\mathrm{C}=$ mass of dry crucible + Sample after drying

\subsubsection{Determination of ash content}

Two grams of the dried sample was measured into a crucible and placed in the muffle furnace at $550^{\circ} \mathrm{C}$ until it was burnt to ash. The crucible and content were then allowed to cool in a desiccator and weighed. This was done repeatedly until a constant weight of the ash was obtained. The percentage ash content was then expressed as percentage of the original weight of the sample on dry basis. The experiment was done in triplicates. Percentage ash content was thus calculated: $\% \mathrm{Ash}=100 \times[\mathrm{C}-\mathrm{B}] /[\mathrm{A}]$

Where $\mathrm{A}=$ weight of sample analyzed

$\mathrm{B}=$ weight of empty crucible 


$$
\mathrm{C}=\text { weight of crucible }+ \text { Ash }
$$

\subsubsection{Determination of crude fat content}

Ten (10) grams of the dried ground sample was weighed and wrapped with a clean filter paper and placed into the thimble in a Soxhlet extractor. A round bottom flask was cleaned, weighed and 120ml of food grade n-hexane added. The flask was connected to the sample holder of the Soxhlet extractor and heated slowly on a mantle for 6 hours. Refluxed n-hexane was recovered and the flask containing the lipid was dried in the moisture extractor in the oven at $60^{\circ} \mathrm{C}$ for few minutes to remove any residual solvent. After drying, the flask containing the oil was cooled in a desiccator and reweighed. By difference, the mass was determined and expressed as the percentage of the fat thus: Percentage $(\%)$ Crude fat $=100 \mathrm{x}$ weight of fat/ weight of sample.

\subsubsection{Determination of crude fibre content}

Two grams $(2 \mathrm{~g})$ of the defatted dried sample was transferred into a 500ml flask, followed by addition of $200 \mathrm{ml}$ of $1.25 \%$ sulphuric acid. The flask was then placed in a digest apparatus on a pre-adjusted hot plate and boiled for 30 minutes with rotation of the flask periodically to prevent solid from adhering to the bottom of the flask. At the end of 30 minutes, the mixture was allowed to stand for one minute, and filtered immediately through the Buchner funnel lined with a muslin cloth. The insoluble matter was washed into the flask for alkali digestion using $0.3 \mathrm{M}$ sodium hydroxide. The digest was boiled for 30 minutes and was allowed to cool for one minute and then filtered using a muslin cloth as before. The residue was then washed successively with $0.1 \mathrm{MHCl}$ and finally with boiling water until it was free of acid. It was then washed twice with alcohol and thrice with ether. The residue or insoluble matter was then transferred into a crucible and dried at $105^{\circ} \mathrm{C}$ in an oven to a constant weight, cooled and weighed. It was then ashed at $550^{\circ} \mathrm{C}$, cooled and weighed. The difference in weight after ashing was then calculated as the fibre content of the sample and was expressed as a percentage of the original weight. The percentage crude fibre content was this calculated:

$\%$ Crude Fibre $=100 \times[\mathrm{B}-\mathrm{C}] /[\mathrm{A}]$

Where $\mathrm{A}=$ weight of sample

$\mathrm{B}=$ weight of sample and crucible after drying at $105^{\circ} \mathrm{C}$

$\mathrm{C}=$ weight of sample (as ash) and crucible after ashing.

\subsubsection{Determination of crude protein content}

The dried ground sample of about $0.8 \mathrm{~g}$ was weighed into an already dried kjeldahl flask. A few drops of water was added to the sample to moisten it, using a burette, $3 \mathrm{ml}$ of conc. $\mathrm{H}_{2} \mathrm{SO}_{4}$ acid was added into the flask followed by the addition of $0.5 \mathrm{~g}$ of $\mathrm{CuSO}_{4}$. The content of the flask was then digested in a fume cupboard with occasional stirring until a clear solution was obtained. The flask was allowed to cool and a small quantity of distilled $\mathrm{H}_{2} \mathrm{O}$ added.

The digest was then transferred into $100 \mathrm{ml}$ volumetric flask and the initial volume recorded. The mixture was shaken thoroughly to obtain a homogenous solution. The mixture was now ready for distillation. The distillation apparatus was steamed for 30 minutes as to get rid of traces of alkali left in the flask. With the aid of a pipette, $10 \mathrm{ml}$ 
of the digest was added to the micro distillation apparatus using a funnel. $10 \mathrm{ml}$ of $50 \% \mathrm{NaOH}$ solution was put in the funnel with measuring cylinder, with stopper glass rod in place. A water condenser set was connected with a $100 \mathrm{ml}$ conical flask used as a receiver which contained $10 \mathrm{ml}$ of $4 \%$ boric acid and two (2) drops of mixed indicator (bromocressol green/methyl red). The drop end of the condenser was immersed well into the boric acid.

The stopper glass rod was gradually removed to allow the $\mathrm{NaOH}$ solution to thoroughly mix with the sample digest solution. The funnel was filled with distilled $\mathrm{H}_{2} \mathrm{O}$ and the steam generator was closed at the top and steam passed into the distillation set. $\mathrm{NH}_{3}$ was liberated and was distilled into $10 \mathrm{ml} 4 \%$ boric acid for 15 minutes. $50 \mathrm{ml}$ of the distillate of blue/green colour was collected and the drip end of the condenser was washed with distilled water into the $100 \mathrm{ml}$ conical flask containing the distillate.

The distillate was then titrated against $0.1 \mathrm{M}$ hydrochloric acid till it changed to pink colour. A reagent blank was run as a control and the protein content was then calculated by multiplying Nitrogen obtained with the factor of 6.25 , expressed on dry basis. The experiment was carried out in triplicates.

The formula for $\%$ crude protein is given below:

$\%$ Protein $=\% \mathrm{~N}_{2} \times 6.25$

$\% \mathrm{~N}_{2}=\mathrm{T}-\mathrm{B}[100 \times \mathrm{N} \times 0.014 \times \mathrm{Vt}] /[\mathrm{W} \times \mathrm{Va}]$

Where $\mathrm{W}=$ weight of sample; $\mathrm{N}=$ Normality of titrant; $\mathrm{Vt}=$ Total digest volume; $\mathrm{Va}=$ Volume of digest analyzed; $\mathrm{T}=$ Sample titre value; $\mathrm{B}=$ Blank titre value .

\subsubsection{Determination of carbohydrate content}

Carbohydrate content was determined by the difference method. This was done by summing up the ( $\%$ moisture, $\%$ protein, $\%$ fat, $\%$ ash, and $\%$ crude fiber) contents and then subtracting their sum from 100. It was also expressed in percentage $(\%)$.

\subsubsection{Determination of caloric value}

Caloric value was calculated as a summation of multiplication of protein, fat, and carbohydrate with their respective water factors of 4,9 and 4 .

\subsection{Anti-nutrient analysis of the unfermented and fermented seeds}

\subsubsection{Determination of phytate}

Phytate content was determined using the method described by ${ }^{[19]}$. Spectrophotometric method was used in the determination of phytate. $1 \mathrm{~g}$ of the pulverized sample was dissolved in $25 \mathrm{ml}$ of $0.5 \mathrm{M} \mathrm{HNO}_{3}$ and centrifuged at 4,000rpm for $10 \mathrm{~min}$. $1 \mathrm{ml}$ of $0.03 \mathrm{M}$ Ferric solution was added to the supernantant and left to stand for $15 \mathrm{~min}$ in order to allow chelation of the iron molecules by the indigenous plant phytate.

At the end of the incubation, it was capped and heated for $20 \mathrm{~min}, 7.5 \mathrm{ml}$ of distilled water was added to it and vortexed. Thereafter, $0.1 \mathrm{ml}$ of $1.33 \mathrm{M} \mathrm{NH}_{4} \mathrm{SCN}$ (Ammonium sulphocyanide) solution was added and absorbance read at $465 \mathrm{~nm}$. The amount of phytate was extrapolated from a standard calibration curve. 


\subsubsection{Determination of saponin}

Saponin composition was determined using the gravimetric method ${ }^{[20]}$. Exactly $220 \mathrm{ml}$ of $20 \%$ ethanol was added to $10 \mathrm{~g}$ of the pulverized samples and stirred using a magnetic stirrer for 12 hours at $55^{\circ} \mathrm{C}$. The solution was filtered using Whatman No 1 filter paper and the extract was reduced to $40 \mathrm{ml}$ under vacuum and $20 \mathrm{ml}$ Diethyl ether was added in a separating funnel and shaken vigorously. The ether layer was discarded while the $\mathrm{pH}$ of the aqueous solution was adjusted to 4.5 by adding $\mathrm{NaOH}$. $60 \mathrm{ml}$ of $\mathrm{n}$-butanol was finally used for extraction. The Butanol extract were washed twice with $10 \mathrm{ml}$ of $5 \% \mathrm{NaCl}$ and evaporated to dryness in a fume cupboard to give a crude saponin which was weighed.

\subsubsection{Determination of total tannin}

Five (5) grams of the samples were weighed into a $50 \mathrm{ml}$ plastic bottle. $1 \mathrm{ml}$ of distilled water was added and shaken for $1 \mathrm{~h}$ in a mechanical shaker. This was filtered into a $50 \mathrm{ml}$ volumetric flask and made up to the mark. Then $1 \mathrm{ml}$ of the filtered was pipetted out into a test tube and mixed with $0.2 \mathrm{ml}$ of $0.1 \mathrm{M} \mathrm{FeCl}_{3}$ in $0 . \mathrm{I} \mathrm{N} \mathrm{HCl}$ and $0.008 \mathrm{M}$ potassium ferrocyanide. The absorbance was measured at $120 \mathrm{~nm}$ within $10 \mathrm{~min}^{[21]}$.

\subsubsection{Determination of oxalate}

The titration method ${ }^{[22]}$ was used in the determination of oxalates. Two (2) grams of sample was suspended in a mixture of $190 \mathrm{ml}$ of distilled water and $10 \mathrm{ml}$ of $6 \mathrm{~N} \mathrm{HCl}$ in a $250 \mathrm{ml}$ volumetric flask and digested for one hour at $100{ }^{\circ} \mathrm{C}$, cooled and made up to $200 \mathrm{ml}$ with distilled water.

The digest was be filtered through Whatman No. 1 Filter paper. A duplicate proportion of $125 \mathrm{ml}$ of the filtrate was measured into $250 \mathrm{ml}$ beakers and 4 drops of methyl red indicator add into each beaker. Concentrated $\mathrm{NH}_{4} \mathrm{OH}$ solution was added drop wise until the test solution changed from its salmon pink color to a faint yellow color $(\mathrm{pH}$ 4-4.5). Each portion was heated up to $90{ }^{\circ} \mathrm{C}$ and $10 \mathrm{ml}$ of $5 \% \mathrm{CaCl}_{3}$ was added while being stirred constantly. After heating, it was cooled and left over night at $5{ }^{\circ} \mathrm{C}$. The supernatant was decanted and the precipitate completely distilled in $10 \mathrm{ml}$ of $20 \%(\mathrm{v} / \mathrm{v}) \mathrm{H}_{2} \mathrm{SO}_{4}$ solution. At this point, the filtrate resulting from digestion of $2 \mathrm{~g}$ of the sample was combined and made up to $300 \mathrm{ml}$. Aliquots $(125 \mathrm{ml})$ of the filtrate was heated until near-boiling and then titrated against $0.05 \mathrm{M}$ standard $\mathrm{KMnO}_{4}$ solution to a faint pink color. Oxalic acid content was calculated using the formula:

Oxalate $(\mathrm{mg} / 100 \mathrm{~g})=\left[\mathrm{T} \times\left(\mathrm{V}_{\mathrm{me}}\right)(\mathrm{Df}) \times 10^{5} \mathrm{~J}\right.$ ME x Mf

Where: $\mathrm{T}=$ Titre of $\mathrm{KMnO}_{4} ; \mathrm{V}_{\mathrm{me}}=$ Volume-mass equivalent (i.e., $1 \mathrm{ml}$ of $0.05 \mathrm{M} \mathrm{KMnO}_{4}$ solution is equivalent to $0.00225 \mathrm{~g}$ anhydrous oxalic acid); $\mathrm{Df}=$ The dilution factor; $\mathrm{ME}=$ The molar equivalent of $\mathrm{KMnO}_{4}$ in oxalic acid; $\mathrm{Mf}$ $=$ The mass of sample used.

\subsubsection{Determination of cyanide (HCN)}

Cyanide content was determined according to the well described procedures ${ }^{[23]}$. Some of the sample was weighed into a conical flask and $50 \mathrm{ml}$ of distilled water was added to it and the solution was allowed to stand overnight and then filtered. $1 \mathrm{ml}$ of the sample filtrate was measured into a test tube and $4 \mathrm{ml}$ of alkaline picrate was added and it was allowed to stand for $5 \mathrm{~min}$. The absorbance was read (with the reagent blank at zero) at $490 \mathrm{~nm}$. 


\subsection{Growth parameters monitored}

Growth parameters measured on a weekly basis were weight gain and feed intake. Feed conversion ratio was calculated as a secondary data.

i. Weight gain: this was gotten by the difference of final and initial body weight.

ii. Feed intake: this was gotten by the difference of feed left in the feeding trough and the initial known quantity served to the rats.

iii. Feed conversion ratio: was gotten by dividing feed intake by the weight gain.

\subsection{Statistical analyses}

Data generated from proximate analysis, anti-nutrient analysis and growth indices of experimental animals were expressed as mean \pm SEM and analysed with ANOVA. Significant differences between groups were separated using the LSD test at $\mathrm{P} \leq 0.05$. SPSS version 20.0 was used for data analysis.

\section{Results}

\subsection{Proximate composition and anti-nutrient profile of unfermented and fermented P. biglobosa seeds}

The proximate composition of the seeds is presented in table 2. The moisture content was higher $(\mathrm{P} \leq 0.05)$ in the fermented seeds than in the unfermented seeds. Crude protein content was on a steady significant rise $(\mathrm{P} \leq 0.05)$ from $23.40 \%$ in the unfermented seeds to $37.40 \%$ in the fermented seeds obtained after the 3rd day of fermentation (D3F). Carbohydrate content showed substantial reduction $(\mathrm{P} \leq 0.05)$ as fermentation time increased.

Crude fat content increased $(\mathrm{P} \leq 0.05)$ from $21.60 \%$ in the unfermented seeds to $28.10 \%$ in the seeds obtained after the $3^{\text {rd }}$ day of fermentation (D3F)as fermentation time increased. No significant observable change $(\mathrm{P}>0.05)$ for the ash composition of the seeds. Crude fiber showed significant reduction $(\mathrm{P} \leq 0.05)$ as fermentation time increased. Caloric value showed marked increase $(\mathrm{P} \leq 0.05)$ from $427.60 \mathrm{kcal}$ in unfermented seeds to $475.30 \mathrm{kcal}$ in the seeds obtained after the 3rd day of fermentation (D3F) as fermentation time increased.

Fermenting the seeds caused significant reduction $(\mathrm{P} \leq 0.05)$ in the levels of the various anti-nutrients. Levels of phytate, saponins, tannins, oxalate and cyanide showed significant reduction $(\mathrm{P} \leq 0.05)$ as fermentation time increased. Their significant percentage reductions are reported in table 3.

\subsection{Growth indices of experimental animals}

Table 4 shows the growth indices of the experimental animals. The fermented seeds significantly improved $(\mathrm{P} \leq 0.05)$ growth performance of the Wistar rats. Significantly higher $(\mathrm{P} \leq 0.05)$ weight gain (growth rate) was observed in rats fed with the fermented seeds with the seeds obtained after 3rd day of fermentation (D3F) yielding the highest weight gain when compared to other fermented products.

Feeding rate was higher in the groups fed with unfermented seeds and the NC group than in the groups fed with the fermented seeds and the difference was significant $(\mathrm{P} \leq 0.05)$. The groups fed with fermented products had lower $(\mathrm{P} \leq 0.05)$ feed conversion ratios against the rats fed with the unfermented seeds. 
Asian Journal of Basic Science \& Research Volume 3, Issue 2, Pages 10-23, April-June 2021

Table 2. Proximate composition of the unfermented and fermented seeds (dried)

\begin{tabular}{|c|c|c|c|c|}
\hline \multirow{2}{*}{ PARAMETER } & \multirow{2}{*}{ UNFERMENTED } & \multirow{2}{*}{$\begin{array}{c}\text { DAY 1 } \\
\text { FERMENTED }\end{array}$} & \multirow{2}{*}{$\begin{array}{c}\text { DAY } 2 \\
\text { FERMENTED }\end{array}$} & \multirow{2}{*}{$\begin{array}{c}\text { DAY } 3 \\
\text { FERMENTED }\end{array}$} \\
\hline & & & & \\
\hline MOISTURE (\%) & $8.17 \pm 0.04^{\mathrm{b}}$ & $8.79 \pm 0.02^{\mathrm{a}}$ & $8.82 \pm 0.06^{\mathrm{a}}$ & $9.37 \pm 0.11^{\mathrm{c}}$ \\
\hline PROTEIN (\%) & $23.40 \pm 0.62^{\mathrm{b}}$ & $27.50 \pm 0.07^{\mathrm{a}}$ & $31.80 \pm 0.05^{\mathrm{d}}$ & $37.40 \pm 0.72^{\mathrm{c}}$ \\
\hline $\mathrm{ASH}(\%)$ & $2.50 \pm 0.01^{\mathrm{a}}$ & $2.40 \pm 0.02^{\mathrm{a}}$ & $2.31 \pm 0.00^{\mathrm{a}}$ & $2.30 \pm 0.10^{\mathrm{a}}$ \\
\hline FIBRE $(\%)$ & $9.40 \pm 0.15^{\mathrm{b}}$ & $7.25 \pm 0.31^{\mathrm{a}}$ & $5.01 \pm 0.30^{\mathrm{d}}$ & $4.60 \pm 0.16^{\mathrm{c}}$ \\
\hline FAT (\%) EE & $21.60 \pm 0.02^{\mathrm{b}}$ & $24.70 \pm 0.01^{\mathrm{a}}$ & $25.16 \pm 0.03^{\mathrm{a}}$ & $28.10 \pm 0.02^{\mathrm{c}}$ \\
\hline CARBOHYDRATE (\%) & $34.90 \pm 0.02^{\mathrm{c}}$ & $30.25 \pm 0.01^{\mathrm{b}}$ & $26.21 \pm 0.04^{\mathrm{a}}$ & $18.20 \pm 0.02^{\mathrm{d}}$ \\
\hline $\begin{array}{l}\text { CALORIC VALUE } \\
\text { (Kcal) }\end{array}$ & $427.60 \pm 0.20^{\mathrm{a}}$ & $444.30 \pm 0.22^{\mathrm{c}}$ & $462.98 \pm 0.41^{\mathrm{d}}$ & $475.30 \pm 0.15^{b}$ \\
\hline
\end{tabular}

Values are expressed as Mean \pm SEM of triplicate determinations

Values with same superscript letter along each row are not significantly different $(\mathrm{P}>0.05)$.

Table 3. Anti-nutrient profile of unfermented and fermented seeds (dried) and percentage reduction compared to unfermented sample

\begin{tabular}{|c|c|c|c|c|}
\hline \multirow{2}{*}{ PARAMETER } & \multicolumn{2}{|r|}{ DAY 1} & DAY 2 & \multirow{2}{*}{$\begin{array}{c}\text { DAY } 3 \\
\text { FERMENTED }\end{array}$} \\
\hline & UNFERMENTED & FERMENTED & FERMENTED & \\
\hline Phytate (mg/100g) & $141.40 \pm 4.62^{\mathrm{a}}$ & $\begin{array}{c}122.50 \pm 3.07^{\mathrm{b}} \\
(13.4 \%)\end{array}$ & $\begin{array}{c}109.80 \pm 3.12^{\mathrm{d}} \\
(22.3 \%)\end{array}$ & $\begin{array}{c}82.40 \pm 2.72^{\mathrm{c}} \\
(41.7 \%)\end{array}$ \\
\hline Saponin (mg/g) & $44.30 \pm 1.05^{\mathrm{b}}$ & $\begin{array}{c}19.20 \pm 0.21^{\mathrm{c}} \\
(56.7 \%)\end{array}$ & $\begin{array}{c}17.31 \pm 0.04^{\mathrm{d}} \\
(60.9 \%)\end{array}$ & $\begin{array}{c}11.24 \pm 0.09^{\mathrm{a}} \\
(74.6 \%)\end{array}$ \\
\hline Tannin (mg/g) & $2.40 \pm 0.30^{\mathrm{d}}$ & $\begin{array}{c}2.32 \pm 0.20^{\mathrm{a}} \\
(3.3 \%)\end{array}$ & $\begin{array}{c}1.88 \pm 0.12^{\mathrm{b}} \\
(21.6 \%)\end{array}$ & $\begin{array}{c}1.00 \pm 0.06^{\mathrm{c}} \\
(58.3 \%)\end{array}$ \\
\hline Oxalate (mg/100g) & $16.60 \pm 0.62^{\mathrm{a}}$ & $\begin{array}{c}11.70 \pm 1.01^{\mathrm{b}} \\
(29.5 \%)\end{array}$ & $\begin{array}{c}11.57 \pm 0.43^{\mathrm{b}} \\
(30.3 \%)\end{array}$ & $\begin{array}{c}8.10 \pm 0.30^{c} \\
(51.2 \%)\end{array}$ \\
\hline Cyanide (mg/g) & $1.08 \pm 0.12^{\mathrm{c}}$ & $\begin{array}{c}0.55 \pm 0.09^{\mathrm{a}} \\
(49.1 \%)\end{array}$ & $\begin{array}{c}0.41 \pm 0.11^{\mathrm{b}} \\
(63.8 \%)\end{array}$ & $\begin{array}{c}0.09 \pm 0.01^{\mathrm{d}} \\
(91.7 \%)\end{array}$ \\
\hline
\end{tabular}

Values are expressed as Mean \pm SEM of triplicate determinations

Values with same superscript along each row were not significantly different $(\mathrm{P}>0.05)$.

Values in parentheses show the $\%$ reductions. 
Table 4. Growth indices of the experimental animals

\begin{tabular}{lccc}
\hline \multicolumn{1}{c}{ GROUPS } & $\begin{array}{c}\text { Growth rate } \\
(\mathrm{g} / 21 \text { days })\end{array}$ & $\begin{array}{c}\text { Feed intake } \\
(\mathrm{g} / 21 \text { days })\end{array}$ & $\begin{array}{c}\text { Feed conversion ratio } \\
(\mathrm{g} / 21 \text { days })\end{array}$ \\
\hline NC & $62.27 \pm 0.05^{\mathrm{e}}$ & $429.40 \pm 1.00^{\mathrm{e}}$ & $6.71 \pm 0.74^{\mathrm{f}}$ \\
$20 \%$ UF & $46.86 \pm 0.21^{\mathrm{a}}$ & $422.35 \pm 0.03^{\mathrm{b}}$ & $9.06 \pm 0.03^{\mathrm{b}}$ \\
$50 \%$ UF & $46.04 \pm 0.25^{\mathrm{a}}$ & $426.30 \pm 1.02^{\mathrm{b}}$ & $9.45 \pm 0.02^{\mathrm{a}}$ \\
$20 \%$ D1F & $54.48 \pm 0.04^{\mathrm{b}}$ & $375.05 \pm 0.40^{\mathrm{c}}$ & $6.85 \pm 0.02^{\mathrm{f}}$ \\
$50 \%$ D1F & $48.32 \pm 1.01^{\mathrm{a}}$ & $361.35 \pm 0.30^{\mathrm{a}}$ & $7.64 \pm 0.10^{\mathrm{c}}$ \\
$20 \%$ D2F & $51.92 \pm 0.09^{\mathrm{c}}$ & $400.90 \pm 0.34^{\mathrm{b}}$ & $7.89 \pm 0.02^{\mathrm{c}}$ \\
$50 \%$ D2F & $51.40 \pm 0.23^{\mathrm{c}}$ & $363.15 \pm 0.50^{\mathrm{a}, \mathrm{c}}$ & $6.96 \pm 0.40^{\mathrm{e}}$ \\
$20 \%$ D3F & $55.16 \pm 0.02^{\mathrm{d}}$ & $361.85 \pm 0.01^{\mathrm{c}}$ & $6.40 \pm 0.30^{\mathrm{d}}$ \\
$50 \%$ D3F & $57.76 \pm 0.60^{\mathrm{d}}$ & $362.70 \pm 0.20^{\mathrm{c}}$ & $6.25 \pm 0.05^{\mathrm{d}}$ \\
\hline
\end{tabular}

Values are expressed as Mean \pm SEM, $n=6$.

Values with same superscript letter on each column are not significantly different $(\mathrm{P}>0.05)$.

\section{Discussion and Conclusion}

The result for proximate composition revealed that fermentation caused changes in the nutrient parameters of the seeds. Moisture, protein and fat content were increased by fermentation whereas fibre and carbohydrate content were decreased by fermentation. Increase in moisture content was highest in the 3-day fermented seeds and this could be attributed to the fact that the unfermented seeds had a higher dry matter content and could also have resulted from the activity of fermenting organisms on the substrate.

The crude protein of the seeds increased as fermentation time increased may be due to the activities of the fermenting organisms in the converting carbohydrates to protein. This was in agreement with other findings on African locust bean seeds ${ }^{[24]}$. Crude fat increased as fermentation time increased and this finding agreed with other research outcomes ${ }^{[8]}$ and this could be due to the fermenting organisms not utilizing fat from these products for energy ${ }^{[25]}$. Fermentation did not alter the ash content of the seeds. Crude fibre decreased in the seeds obtained after 3-day fermentation. This decrease could be due to the activities of fermenting organisms in the bio-conversion of lignocelluloses into protein ${ }^{[26]}{ }^{[27]}$. Carbohydrate content decreased as fermentation time increased and this reduction agrees with the reports of earlier workers ${ }^{[8]}{ }^{[28]}$.

The fermenting organisms may have utilized sugars for energy. Caloric value increased with as fermentation time increased. This increase in caloric value is likely to be connected with the increase in the fat content of fermented seeds as fats on its own contain about twice the energy values of protein and carbohydrate. It also could be attributed to the increased metabolic activities by the fermenting organisms resulting in the release of energy. 
The results for anti-nutrient profile reveal that fermentation reduced the anti-nutrient content of the seeds. The phytic acid content of the seeds decreased in the seeds obtained after 3-day fermentation. Phytic acid binds metals and renders them unavailable thereby preventing their absorption in the body ${ }^{[29]}$. Phytase enzyme inherent in fermenting organisms breaks down phytic acid to yield inositol and orthophosphoric acid ${ }^{[26]}$. The saponin and tannin composition of the seeds also decreased in the seeds obtained after 3-day fermentation. Tannins are known inhibitors of metals and if sustained, could lead to serious disorders (e.g. anaemia) ${ }^{[30]}$.

Fermentation is therefore one of the processes utilized to circumvent the negative effects of tannins ${ }^{[31]}$. The partial oxidation of carbohydrates results in the synthesis of oxalates. Oxalate forms insoluble precipitates with metal ions, such as in calcium oxalate, which is strongly linked to the formation of kidney stones ${ }^{[32]}$. Cyanide has been reported to affect oxidative phosphorylation ${ }^{[33]}$. From the results fermentation reduced the levels of oxalate and cyanide as fermentation time increases. Thus, reduction of these potentially toxic anti-nutrients by fermentation made the fermented seeds safer for human consumption.

Body weight gain measurement in an experimental study is useful and forms part of the evaluation of the nutritional quality of a diet. Groups fed with the fermented seeds at $20 \%$ and $50 \%$ inclusion levels were observed to record higher body weight gain against those fed with the unfermented products. This could be attributed to the higher contents of protein and fats in the fermented seeds of P. biglobosa. However, a higher and feed intake was recorded in the groups fed with unfermented products when compared to those fed with the fermented products. This could be attributed to the organoleptic properties of fermented P. biglobosa seeds. The pungent smell of the fermented seeds is responsible for the lower feed intake observed and this was prominent in the first few days of animal feeding although as days went by, their feed intake improved. The measure of the rate at which an animal coverts feed mass to body mass defines feed conversion ratio (FCR). High quality feed usually have a low FCR ${ }^{[34]}$.

From the results, the FCRs for groups fed with fermented products were lower than those fed with the unfermented products. The group fed with 50\% D3F products had the lowest FCR and was lower than the normal control. This observation is attributable to the fact that as the protein content of a diet increases, the FCR gets smaller ${ }^{[34]}$. Thus, fermenting the seeds of $P$. biglobosa improved the growth performance of the experimental rats implying that inclusions of the portions of fermented seeds improved the quality of the feeds fed to the animals.

\section{Declarations}

\section{Source of Funding}

This research did not receive any specific grant from funding agencies in the public, commercial, or not-for-profit sectors.

\section{Competing Interests Statement}

The authors declare no competing financial, professional and personal interests.

\section{Consent to participate}

Not Applicable 


\section{Consent for publication}

We declare that we consented for the publication of this research work.

\section{Availability of data and material}

Authors are willing to share data and material according to the relevant needs.

\section{References}

1. Ken, F. (2014). Useful tropical plants: P. biglobosa. Useful tropical plants database. Web: http//tropical.theferns.info/viewtropical.php?id=parkia+biglobosa.

2. Hopkins, H. C., (1983). The taxonomy, reproductive biology and economic potential of fermented food product, dawadawa. Ecology of Food and Nutrition, 9: 123-132.

3. Hall, L.S., Krausman, P. R. and Morrison, M. L. (1997). The habitat concept and a plea for standard terminology. Wildlife Society Bulletin, 25(1): 173-182.

4. Campbell-Platt, G. (1980). African locust bean (Parkia Species) and its West African fermented food product, dawadawa. Ecology of Food Nutrition, 9: 123-132.

5. Tybirk, K. (1991). Regeneration of Woody Legumes in Sahel. AAU Reports. Univ. of Aarhus. Denmark. 82pp. 6. Babalola, F. D. (2012). Evaluation of marketing chain of Parkiabiglobosain South-West Nigeria. International Journal of Basic and Applied Sciences, 1(3): 210-217.

7. Hassan, L. G. and K. J. Umar (2005). Protein and amino acids composition of African locust bean (Parkiabiglobosa). Tropical and Subtropical Agroecosystems, 5: 45-48.

8. Esenwah, C. N. and Ikenebomeh, M. J. (2008). Processing effects on the nutritional and antinutritional contents of African locust bean (P. biglobosa Benth.) seed. Parkistan Journal of Nutrition, 7(2): 214-217.

9. Odunfa, S. A. (1981). Microorganisms associated with fermentation of African locust bean (Parkiafilicoidea) during iru preparation. Journal of Plant Foods, 3: 245-250.

10. Antai, S. P., Ibrahim, M. H. (1986). Micro-organisms associated with African locust bean fermentation for 'dawadawa' production. Journal of Applied Bacteriology. 61: 145-148.

11. Omolara, O. Oluwaniyi and Ibrahim, O. Bazambo. (2014). Antinutritional and phytochemical evaluation of raw and fermented African locust bean (Parkia biglobosa) seeds. Global Journal of Pure and Applied Sciences, 20 : 105-109.

12. Ndukwe, M. N. and Solomon, M. D. (2017). Proximate and antinutrient composition of some local food condiments in their raw and fermented forms. International J. of Biochemistry Research and Review, 20(1): 1-8.

13. Thangeraj, P. (2016). Proximate composition analysis. In: Pharmacological assays of plant-based natural products. Progress in drug Research, vol 71. Springer, cham. 
14. Gemede HF, Ratta N. Antinutritional factors in plant foods: potential health benefits and adverse effects. Int J Nutri Food Sci 2014; 3(4): 284-9.

15. Essack H, Odhav B, Mellem J. (2017). Screening of traditional South African leafy vegetables for selected anti-nutrient factors before and after processing. Food Science Technology; 3: 462-1.

16. Soetan $\mathrm{K}$, Oyewole $\mathrm{O}$. The need for adequate processing to reduce the anti-nutritional factors in plants used as human foods and animal feeds: A review. Afr J Food Sci 2009; 3(9): 223-32.

17. Reddy, N. R. and M. D. Pierson (1994). "Reduction in antinutritional and toxic components in plant foods by fermentation." Food Research International 27: 281.

18. A.O.A.C. (2000). Official methods of analysis of AOAC. 17th ed. Association of Official Analytical Chemists (AOAC) International, Gaithersburg.

19. Reddy, M. B. and Love, M. (1999). The impacts of food processing on the nutritional quality of vitamins and minerals. Advanced Experimental Medical Biology, 459: 99-106.

20. Hudson, B. J. and El-Difrawi, E. A. (1979). The sapogenins of the seeds of four lipin species. Journal of Plant Food, 3: 181-186.

21. Van-Burden, T. and Robinson W. (1981). Formation of complexes between protein and tannic acid. Journal of Agricultural Food Chemistry, 1:77.

22. A.O.A.C. (2010). Official methods of analysis of AOAC. 17th ed. Association of Analytical Chemists (AOAC) International, Washington DC, USA.

23. Onwuka, G. I. (2005). Food analysis and implementation: theory and practice. 1st ed. Naphtali prints, Lagos. $190 \mathrm{pp}$.

24. Omafuvbe, B. O., Falade, O. S., Osuntogun, B. A., Adewusi, S. (2004). Chemical and biochemical changes in African Locust Bean (Parkia Biglobosa) and Melon (Citrullus Vulgaris) seeds during fermentation to condiments. Pakistan Journal of Nutrition, 3 (3): 140-145.

25. Reebe, S., Gonzalez, V. N. and Rengilo, J. (2000). Research on trace elements in common beans. Food Nutrition Bulletin, 21: 387-391.

26. Igbabul, B. D., Amove, J. and Twadue, I. (2014). Effect of fermentation on the proximate composition, antinutritional factors and functional properties of cocoyam (Colocasiaesculenta) flour. African Journal of food Science and Technology, 5(3): 67-74.

27. Emmanuel, I., Aladesanmi, O., Adekunle, O. and Oluwafemi, O. (2017). Effect of fermentation on the phytochemical properties and nutritionally valuable minerals of Locust bean (Parkiabiglobosa). American Journal of Food Technology, 12: 379-384.

28. Omodara, T. R. and Olowomofe, T. O. (2013). Effect of fermentation on the nutritional quality of African locust bean and soybean. International Journal of Science and Research, 1: 2319-2364. 
29. Omolara, O. O. and Ibrahim, O. B. (2014). Antinutritional and phytochemical evaluation of raw and fermented African locust bean (Parkiabiglobosa) seeds. Global Journal of Pure and Applied Sciences, 20: 105-109.

30. Igwenyi, I. O., Ezeifedika, O. M., Agbafor, K. N., Offor, C. E., Ibiam, U. A. and Aja, P. M. (2014). Antinutritional factors in Afzeliaafrcana and Citrulluscolocynthis and effects of the seeds on liver enzyme activities of albino rats. Indian Journal of Science and Technology, 1: 1-6.

31. Dicko, M. H., Gruppen, H., Traore, A. S., Van Berkel, W. J. and Voragin, A. G. (2008). Evaluation of the effects of germination on phenolic compounds and antioxidant activities in sorghum varieties. Journal of Agricultural and Food Chemistry, 53: 2581-2588.

32. Engin, K. N. and Engin, G. K. (2007). Clinical evaluation of the neuroprotective effect of alpha-tocopherol against glaucomatous damage. European Journal of Opthalmology, 17(4): 528-533.

33. Voet, D. and Voet, J. G. (2004). Electron transport and oxidative phosphorylation. Biochemistry Publication, 1: 797-842.

34. USAID (United States Agency for International Development) (2011). Helping address rural vulnerabilities and ecosystem stability: Technical Bulletin. Phnom Penh, Cambodia. 